\title{
Taxonomic Conceptions of Algae, Animals, Fungi and Plants in Granting Intellectual Property Privileges
}

\author{
Charles Lawson ${ }^{*}$
}

\begin{abstract}
Both the Plant Breeder's Rights Act 1994 (Cth) and the Patents Act 1990 (Cth) establish schemes that grant exclusivity to some, but not other, biological organisms. The purpose of this article is to examine the interface between what 'plants', 'animals', 'algae' and 'fungi' are included and excluded from these schemes, addressing the epistemic rules of taxonomy (the classification of organisms) and the related nomenclature (the naming codes). The outcome of this analysis demonstrates that the existing conceptions of biological organisms in both statutory schemes are poorly articulated, but that a conception of suitably protectable biological organisms may be addressed through taxonomy and the naming codes. Significantly, however, taxonomy and the naming codes do not provide a definitive standard, though they may be a useful proxy for reducing organisms to the objects of law.
\end{abstract}

\section{Introduction}

The Plant Breeder's Rights Act 1994 (Cth) (PBR Act) and the Patents Act 1990 (Cth) (Patents Act) establish statutory schemes that grant exclusivity to certain dealings with biological organisms. ${ }^{1}$ Both schemes, however, include and exclude certain kinds of biological organisms, using terminology that is poorly crafted so that the interface between what is included, and what is excluded, remains uncertain. ${ }^{2}$ The concern of this article is that the

Associate Professor, Australian Centre for Intellectual Property in Agriculture, Griffith Law School. I acknowledge and appreciate the assistance, guidance and suggestions from Catherine Pickering, Stephen Hubicki, the editors and the anonymous referees, although I accept all responsibility for this work. This work was supported by an Australian Research Council grant to research 'Promoting Plant Innovation in Australia: Maximizing the Benefits of Intellectual Property for Australian Agriculture', DP0987639.

See Plant Breeder's Rights Act 1994 (Cth), s 11; Patents Act 1990 (Cth), s 13(1). There may be the potential for other intellectual property schemes to apply to various biological organisms: see, for example, Ludlow (1999a, 1999b).

2 Perhaps surprisingly, the conception and definition of 'plants', 'animals', 'fungi' and 'algae' have not been addressed in recent inquiries into the Plant Breeder's Rights Act 1994 (Cth) and the Patents Act 1990 (Cth): see, for examples, Advisory Council on Intellectual Property (2004, 2008); Australian Law Reform Commission (2004a, 2004b); Expert Panel on Breeding (2002); Standing Committee on Legal and Constitutional Affairs, House of Representatives (2001), and so on. 
terminology of inclusion and exclusion used in both the PBR Act and the Patents Act fails to meaningfully conceptualise what biological organisms are suitable subject-matter for these statutory privileges. The pressure points of particular concern addressed in this article are the meanings of the terms 'plant' (including 'fungi' and 'algae') for 'plant breeder's rights' (PBR) under the PBR Act and 'plants' and 'animals' for an 'innovation patent' under the Patents Act. While this might appear to be a minor technicality, its consequences are significant as the scope of the PBR Act and the scope of some exclusions under the Patents Act are determined by the meanings of these terms. Thus the purpose of the article is to examine whether the imprints of taxonomy (the classification of organisms) ${ }^{3}$ and the related nomenclature (the naming codes) echoed in the PBR Act and the Patents Act provide a useful means of conceptualising biological organisms. In other words, this analysis considers the passive use of conventions practised in other disciplines (epistemic cultures) to define the objects of law, thereby becoming a part of the scaffolding of law themselves. In this case, it is the interaction between taxonomy and naming codes, and their contribution to defining the legal object for market exclusivity under the economic instruments defined by PBR Act and the Patents Act. The analysis also illustrates the extra-legal interpretation of the content of law as many of the basic concepts in PBR and patent law remain to be adjudicated by courts, and so the existing practice of IP Australia in its interpretation and implementation determine the content and meanings of key terms. This accepts and acknowledges, of course, that only a court can finally decide the matter.

The article is structured as follows: the next two sections map the statutory schemes in the PBR Act and the Patents Act, addressing biological organisms; the following two sections consider the likely application of taxonomy and the related naming codes to biological organisms that might be defined as 'plants' (including 'fungi' and 'algae') and 'animals' in the context of the PBR Act and the Patents Act, demonstrating the instability in taxonomy and the arbitrariness of naming codes as consistent determinants of definition; and the article concludes that taxonomy and the related naming codes do assist in usefully conceptualising 'plants', 'animals', 'fungi' and 'algae' under the PBR Act and the Patents Act, although final and absolute certainty is unlikely, with the consequence that taxonomy and the related naming codes are a useful proxy for reducing organisms to the objects of law.

The term 'taxonomy' means the describing, classifying and naming of organisms, while the related term 'systematics' involves a broader objective of determining the relationship(s) between organisms, including the methodological and philosophical grouping of similar/related organisms. 


\section{The Plant Breeder's Rights Act 1994 (Cth)}

The PBR Act grants the 'exclusive right' (or the 'plant breeder's right' or 'PBR') $)^{4}$ to a 'breeder's of a 'plant variety' 'to do' or 'to license another person to do' any of the following with the "propagating material' ${ }^{7}$ of the plant variety: 'produce or reproduce the material', 'condition the material for the purpose of propagation', 'offer the material for sale', 'sell the material', 'import the material', 'export the material' and 'stock the material for [any of those] purposes'. ${ }^{8}$ These 'exclusive rights' are then extended to certain 'essentially derived varieties', 9 'dependent plant varieties', ${ }^{10}$ 'harvested material' ${ }^{11}$ and 'products obtained from harvested material'. ${ }^{12}$ The 'exclusive rights' are limited for certain acts done for private, experimental or breeding purposes, ${ }^{13}$ and for certain conditioning and use of farm saved seeds. ${ }^{14}$ The 'exclusive rights' are available for up to 20 years for all varieties, and up to 25 years for trees and vines. ${ }^{15}$

To obtain a PBR, the 'breeder' ${ }^{16}$ must apply 'for the grant of a $P B R$ in the variety' (emphasis added) ${ }^{17}$ by lodging an application, ${ }^{18}$ addressing a number of matters including a brief description of the variety, the name of the variety, the names of the parental varieties and a brief description about how the variety was bred. ${ }^{19}$ The term 'plant variety' (which may also include a genetically modified 'plant') ${ }^{20}$ means, in part, 'a plant grouping (including a hybrid) ... that is contained within a single botanical tax on of the lowest known rank'. ${ }^{21}$ The term 'plant' includes 'all fungi and algae but does not include bacteria, bacteroids, mycoplasmas, viruses, viroids and

Plant Breeder's Rights Act 1994 (Cth), s 3(1).

Plant Breeder's Rights Act 1994 (Cth), s 3(1) ('breeder'). See also Expert Panel on Breeding (2002).

$6 \quad$ Plant Breeder's Rights Act 1994 (Cth), s 3(1) ('plant variety').

Plant Breeder's Rights Act 1994 (Cth), s 3(1) ('propagating material').

Plant Breeder's Rights Act 1994 (Cth), s 11.

Plant Breeder's Rights Act 1994 (Cth), s 12.

Plant Breeder's Rights Act 1994 (Cth), s 13.

Plant Breeder's Rights Act 1994 (Cth), s 14.

Plant Breeder's Rights Act 1994 (Cth), s 15.

Plant Breeder's Rights Act 1994 (Cth), s 16.

Plant Breeder's Rights Act 1994 (Cth), s 17.

Plant Breeder's Rights Act 1994 (Cth), s 22(2).

16 This can include more than one 'breeder': see Plant Breeder's Rights Act 1994 (Cth), s 24(3).

Plant Breeder's Rights Act 1994 (Cth), s 24(1).

See Plant Breeder's Rights Act 1994 (Cth), s 26.

Plant Breeder's Rights Act 1994 (Cth), s 26(2).

Plant Breeder's Rights Act 1994 (Cth), s 6.

Plant Breeder's Rights Act 1994 (Cth), s 3(1) ('plant variety'). 
bacteriophages' ${ }^{22}$ And the term 'hybrid' means 'a plant that is a combination of 2 or more genotypes of the same or different taxa but excluding a combination comprising a scion grafted on to a root stock'. ${ }^{23}$

Thus the subject-matter of a PBR is a 'plant variety'. ${ }^{24}$ This comprises a 'plant grouping' that itself consists of 'plants', 'fungi' and 'algae', but not 'bacteria', 'bacteroids', 'mycoplasmas', 'viruses', 'viroids' and 'bacteriophages'. ${ }^{25}$ The effect of these various definitions is that, for the purposes of the PBR Act, the scope of subject-matter includes 'plants', 'fungi' and 'algae', albeit there is no comprehensive definition of exactly what constitutes a 'plant', a 'fungus' or an 'alga'. A common thread among the various definition provisions is the reference to taxonomic language: something "contained within a single botanical taxon of the lowest known rank', ${ }^{26}$ 'a plant that is a combination of 2 or more genotypes of the same or different $\operatorname{taxa}^{\prime},{ }^{27}$ and 'treated as constituting a plant grouping within a single botanical taxon' (emphasis added). ${ }^{28}$ This suggests that taxonomy may be involved in conceiving what a 'plant variety' is for the purposes of PBR.

Some further interpretive assistance might be found in the provisions of the International Convention for the Protection of New Varieties of Plants (UPOV) that the PBR Act implements in Australia, providing that 'the grant [of a PBR] is appropriate to give effect to the obligations of Australia under the [UPOV] '. ${ }^{29}$ The UPOV requires contracting parties such as Australia to 'grant and protect breeders' rights' to 'all plant genera and species'.$^{30}$ The UPOV defines the term 'variety' using taxonomic language: 'a plant grouping within a single botanical taxon of the lowest known rank' (emphasis added). ${ }^{31}$

Another requirement under the $P B R$ Act is that an application must set out both 'the name of the variety' and 'any proposed synonym for that name'. ${ }^{32}$ Further, the 'name (including a synonym), in respect of a plant variety must comply with the International Code of Botanical Nomenclature and subsidiary codes' ${ }^{33}$ For the purposes of this naming according to the International Code of Botanical Nomenclature, the term 'plant' means 'any

Plant Breeder's Rights Act 1994 (Cth), s 3(1) ('plant').

Plant Breeder's Rights Act 1994 (Cth), s 3(1) ('hybrid').

See Plant Breeder's Rights Act 1994 (Cth), s 11.

See Plant Breeder's Rights Act 1994 (Cth), s 3(1) ('plant' and 'plant variety').

Plant Breeder's Rights Act 1994 (Cth), s 3(1)(a) ('plant variety'). Notably the definition of 'hybrid' also makes reference to 'taxa': s 3(1)(a) ('hybrid')

Plant Breeder's Rights Act 1994 (Cth), s 3(1) ('hybrid').

$28 \quad$ Plant Breeder's Rights Act 1994 (Cth), s 6.

$29 \quad$ Plant Breeder's Rights Act 1994 (Cth), ss 3(1) ('Convention') and 10(a) and Sch 1. See also Lawson (2006).

30 UPOV, Art 3(1).

31 UPOV, Art 1(vi).

$32 \quad$ Plant Breeder's Rights Act 1994 (Cth), ss 3(1) ('synonym') and 26(2)(f).

$33 \quad$ Plant Breeder's Rights Act 1994 (Cth), s 27(6).
} 
organism traditionally studied by botanists' ${ }^{34}$ and applies to 'all organisms traditionally treated as plants'. ${ }^{35}$ Significantly, these rules are applied according to the principle that ' $[\mathrm{b}]$ otanical nomenclature is independent of zoological and bacteriological nomenclature' and 'applies equally to names of taxonomic groups treated as plants whether or not these groups were originally so treated' (emphasis added). ${ }^{36}$ The International Code of Botanical Nomenclature ${ }^{37}$ and subsidiary codes (such as the International Code of Nomenclature for Cultivated Plants, addressing a "precise, stable, and simple system of naming [agricultural, forestry, and horticultural] plants that can be applied internationally' ${ }^{38}$ provide a comprehensive set of rules for naming botanical organisms, including algae, blue-green algae, various fungi such as chytrids, oomycetes and slime moulds, various photosynthetic protists and some of the taxonomically related non-photosynthetic groups (and some fossils). ${ }^{39}$ Significantly, the International Code of Botanical Nomenclature and subsidiary codes (such as International Code of Nomenclature for Cultivated Plants) ${ }^{40}$ generally apply naming rules based on taxonomic groupings: 'The purpose of giving a name to a taxonomic group is not to indicate its characters or history, but to supply a means of referring to it and to indicate its taxonomic rank.' (emphasis added) $)^{41}$

Another naming requirement under the PBR Act is that a 'name (including a synonym), in respect of a plant variety must not ... be likely to deceive or cause confusion, including confusion with the name of another plant variety of the same plant class'. ${ }^{42}$ The term 'plant class' consists of plants that 'belong to a single botanical genus' or 'belong to a group of closely related genera' and that are on the Registrar's List of Plant Classes (emphasis added) ${ }^{43}$ The Registrar's 'List of Plant Classes' then provides a 'General Rule' that 'for genera and species not covered by the List of Classes in this Annex, a genus is considered to be a class', and then 'Exceptions to the General Rule' that are 'Classes within a genus' and International Code of Botanical Nomenclature, Preamble 1 (and footnote) and Appendix 7 ('plant').

35 International Code of Botanical Nomenclature, Preamble 7. International Code of Botanical Nomenclature, Div I (Principle 1). See also McNeill et al (2005).

International Code of Botanical Nomenclature, Preamble 8. See also Brickell et al (2004), p 1.

39 See International Code of Botanical Nomenclature, Preamble 7.

Notably, the International Code of Nomenclature for Cultivated Plants provides: 'The International Code of Botanical Nomenclature governs the names in Latin for both cultivated and wild plants, except for graft chimeras which are entirely governed by this Code': International Code of Nomenclature for Cultivated Plants, Principle 2. International Code of Botanical Nomenclature, Preamble 1.

$42 \quad$ Plant Breeder's Rights Act 1994 (Cth), s 27(5)(a). 
'Classes encompassing more than one genus'. ${ }^{44}$ The effect of this naming scheme is to limit the term 'plant' in the PBR Act to only those organisms capable of being named according to the 'List of Plant Classes' that is itself dependant on the International Code of Botanical Nomenclature and subsidiary codes (and particularly the International Code of Nomenclature for Cultivated Plants) that generally assign names according to taxonomy.

This analysis demonstrates that to be the subject-matter of protection under the PBR Act a 'plant variety' is conceived in the language and application of taxonomy and naming codes. The meaning of 'plant' under the PBR Act in the context of taxonomy and these naming codes is considered further below after an analysis of the relevant parts of the Patents Act.

\section{The Patents Act 1990 (Cth)}

The Patents Act grants the 'exclusive rights' to a 'patentee'45 of a 'standard patent' ${ }^{46}$ (for up to 20 or 25 years), ${ }^{47}$ or an 'innovation patent' ${ }^{48}$ (for up to eight years), ${ }^{49}$ to 'exploit ${ }^{50}$ the invention and to authorize another person to exploit the invention'. ${ }^{51}$ To obtain a 'standard patent' or an 'innovation patent', the applicant ${ }^{52}$ must lodge an application, ${ }^{53}$ and eventually lodge a 'complete specification' ${ }_{54}$ that describes and defines the boundaries of the invention. ${ }^{55}$ A 'patent' may then be granted for a 'patentable invention' ${ }_{56}$ that is an 'invention' ${ }^{57}$ that satisfies various threshold standards including that it be subject-matter suitable for patenting ('a manner of manufacture'). ${ }^{58}$ Thus the subject-matter of a 'patent' is an 'invention'. ${ }^{59}$

Plant Breeder's Rights Act 1994 (Cth), s 61(1A); Registrar of Plant Breeder's Rights (2009). See also International Union for the Protection of New Varieties of Plants (2006), Annex 1.

$45 \quad$ Patents Act 1990 (Cth), s 3 and Sch 1 ('patentee').

Patents Act 1990 (Cth), ss 3 and Sch 1 ('standard patent') and 61.

47 Patents Act 1990 (Cth), ss 67 (20 years) and 77 (extension up to 25 years for some subject-matters).

Patents Act 1990 (Cth), ss 3 and Sch 1 ('innovation patent') and 62.

Patents Act 1990 (Cth), s 68.

Patents Act 1990 (Cth), s 3 and Sch 1 ('exploit').

Patents Act 1990 (Cth), s 13(1).

52 This can include more than one applicant: see Patents Act 1990 (Cth), s 31.

53 See Patents Act 1990 (Cth), s 29. Notably, there is a domestic and international scheme for applications: see IP Australia (2010a) [1.3] (international applications) and [2.2.3] (domestic applications).

$54 \quad$ Patents Act 1990 (Cth), s 3 and Sch 1 ('complete specification').

Patents Act 1990 (Cth), s 40(2).

56 Patents Act 1990 (Cth), s 3 and Sch 1 ('patentable invention').

Patents Act 1990 (Cth), s 3 and Sch 1 ('invention').

$58 \quad$ Patents Act 1990 (Cth), s 18(1) and (1A).

59

See Patents Act 1990 (Cth), s 18(1). 
The term 'manner of manufacture' ${ }^{60}$ has evolved to reflect changing attitudes to the acceptable scope of patentable subject-matter. ${ }^{61}$ The relevant long-established principles now follow the binding authority of the High Court in National Research Development Corporation v Commissioner of Patents. ${ }^{62}$ The current IP Australia consensus appears to be that some subject-matters are not a 'manner of manufacture' and are specifically not patentable, ${ }^{63}$ but this does not include living organisms that are accepted as 'manners of manufacture'. ${ }^{64}$ Whether this perspective is correct has never been settled by the High Court, although the decision in Grain Pool of Western Australia $v$ Commonwealth accepts that 'there is no intrinsic impediment to the patentability of plant varieties' ${ }^{65}$ This would appear to suggest that the mere fact that the subject-matter is living organisms, such as an alga, animal, fungus or plant, is not a barrier to patentability.

Current IP Australia practice regarding the standards for patentability of living organisms is founded on the decision in Ranks Hovis McDougall Ltd's

60 The meaning of 'manner of manufacture' and 'manner of new manufacture' was resolved by the High Court deciding that the significance of the word 'new' was in recognising that: 'If it is apparent on the face of the specification that the quality of inventiveness necessary for there to be a proper subject of letters patent under the Statute of Monopolies is absent, one need go no further.' NV Philips Gloeilampenfabrieken and Philips Lighting Pty Ltd v Mirabella International Pty Ltd (1995) 183 CLR 655 at 664 (Brennan CJ, Deane and Toohey JJ). See also Advanced Building Systems Pty Limited v Ramset Fasteners (Aust) Pty Limited (1998) 194 CLR 171 at 190 (Brennan CJ, Gaudron, McHugh and Gummow JJ). Notably, the Patents Act 1990 (Cth), s 138(3) does not distinguish between the different grounds of 'invention'/'patentable invention', 'novelty' and 'inventive step' in the same way as the Patents Act 1952 (Cth), ss 100(1) and 100(2).

For a recent overview of these developments, see Australian Council on Intellectual Property (2008), pp 17-44. See also Pila (2003). Notably, under the Patents Act 1990 (Cth), the term 'manner of manufacture' was intended to 'mean little more than that an invention must belong to the useful arts rather than the fine arts', and so adopted a 'flexible threshold test of patentability ... in preference to adopting a more inflexible codified definition': Explanatory Memorandum (1989), p 8. See also Industrial Property Advisory Council (1984), p 40.

The decision establishes the oft-cited standard: "The right question is, "Is this a proper subject of letters patent according to the principles which have been developed for the application of s 6 of the Statute of Monopolies?" National Research Development Corporation v Commissioner of Patents (1959) 102 CLR 252 at 269 (Dixon CJ, Kitto and Windeyer JJ). Exactly what these principles are remains contentious - for example, see Hubicki and Sherman (2009), pp 73-96; Monotti (2006).

For an overview of these subject-matters: see IP Australia (2010a), [2.9.2.2]-[2.9.2.17]. See also Australian Council on Intellectual Property (2008), pp 33-34; Lawson (2008); Monotti (2006). See IP Australia (2010a), [2.9.2.14]. See also IP Australia (2005), pp 1-2.

65 Favourably citing the US decision in Diamond $v$ Chakrabarty Diamond $v$ Chakrabarty 447 US 303 (1980) as authority for the proposition 'that live, human-made, microorganisms were patentable subject-matter': Grain Pool of Western Australia v Commonwealth (2000) 202 CLR 479 at 502-3 (Gleeson CJ, Gaudron, McHugh, Gummow, Hayne and Callinan JJ). 
Application. ${ }^{66}$ There IP Australia (then the Australian Patent Office) granted a patent claim for a pure cultured bacterium on the basis that an inventive step had been applied to purifying the naturally occurring organism by 'producing the variant by some man-controlled microbiological process'. ${ }^{67}$ The claim for the isolated strain of the naturally occurring bacterium was refused ${ }^{68}$ but claims were accepted for those bacteria demonstrating some intervention. ${ }^{69}$ The principle applied to living organisms appears to be that potentially any change from a 'natural' state may be patentable (an 'invention'), while in the 'natural' state it will be unpatentable (a 'discovery'). ${ }^{70}$ The distinction between 'invention' and 'discovery' should now be abandoned as ' $\mathrm{t}$ ] he truth is that the distinction between discovery and invention is not precise enough to be other than misleading, ${ }^{71}$ and in its place the relevant inquiry is whether the claimed subject-matter is 'an artificially created state of affairs' with some new and useful effect. ${ }^{72}$ The current IP Australia practice is that 'the isolation and cultivation of naturally occurring micro-organisms satisfy the requirement of a technical intervention' (emphasis added) ${ }^{73}$ Further, '[a] claim to a biologically pure culture of the naturally occurring micro-organism is also acceptable'. ${ }^{74}$ In other words, potentially patentable subject-matter includes any biological organisms, including 'plants' and 'animals' per se, and their parts and

$66 \quad$ (1976) 46 AOJP 3915.

67 Ranks Hovis McDougall Ltd's Application (1976) 46 AOJP 3915 at 3968. This decision was made by the Assistant Commissioner and is not binding on the Federal Court, although the decision has been confirmed by a Patent Office Notice (1980) 50 AOJP 1162 .

$68 \quad$ Ranks Hovis McDougall Ltd's Application (1976) 46 AOJP 3915 at 3968.

$69 \quad$ Ranks Hovis McDougall Ltd's Application (1976) 46 AOJP 3915 at 3968.

70 See National Research Development Corporation v Commissioner of Patents (1959) 102 CLR 252 at 264 (Dixon CJ, Kitto and Windeyer JJ).

$71 \quad$ National Research Development Corporation v Commissioner of Patents (1959) 102 CLR 252 at 264 (Dixon CJ, Kitto and Windeyer JJ). This issue is that in 'nature' the organism (or gene, protein, fragment, molecule, and so on) is discovered, while outside that 'nature' the same organism (or gene, protein, fragment, molecule, and so on) with the same now useful function becomes inventive: see Lawson (2004), pp 98-99.

72 National Research Development Corporation v Commissioner of Patents (1959) 102 CLR 252 at 277 (Dixon CJ, Kitto and Windeyer JJ). In effect, the High Court abandoned one framing of a metaphysical question (discovery/invention) for another (not artificial/artificial) and returned to a conception of invention as a process of making by art or skill: see Hubicki and Sherman (2009), p 91.

73 IP Australia (2010a), [2.7.1] and [2.9.2.14]. Notably, Ranks Hovis McDougall Ltd's Application (1976) 46 AOJP 3915 at 3968 refers to 'some man controlled microbiological process' resulting in 'improved or altered useful properties' so that the IP Australia requirement for 'a technical intervention' must also be 'man controlled' and an 'improvement' which is more than mere 'intervention'. 
components. ${ }^{75}$ The only clear statutory exceptions relating to 'plants' and 'animals' are: ${ }^{76}$ the exclusion from 'standard patents' and 'innovation patents' of '[h]uman beings, and the biological processes for their generation' $;{ }^{77}$ and the exclusion from 'innovation patents' of 'plants and animals' and 'the biological processes for the generation of plants and animals'. ${ }^{78}$ While 'human beings' might be within the meaning of the term 'animals' for the purposes of the Patents Act, this seems unlikely as a dictionary definition of 'animal' includes 'any animal other than a human' (emphasis added), ${ }^{79}$ and the 'human beings' exception has been applied separately as a test of what constitutes 'essentially human characteristics' (that is not defeated by any technological means of how the 'human being' is constituted or created)..$^{80}$ The exclusion from 'innovation patents' of 'plants and animals' and 'the biological processes for the generation of plants and animals' are considered now.

Following an application for an 'innovation patent', the Commissioner of Patents (in IP Australia) must accept the 'patent request' ${ }^{81}$ and 'complete specification" ${ }^{82}$ following a 'formalities check'. ${ }^{83}$ Subsequently, the

75 See IP Australia (2005). Notably, while it may be possible for a depositary authority to accept any organisms, or parts of any organism, this does not appear to be the general practice, and has not been the practice in Australian depositary authorities: see World Intellectual Property Organisation (2010), Part II, pp 10-17.

Other exclusions for: 'standard patents' - inventions that are 'generally inconvenient' (Patents Act 1990 (Cth), ss 18(1), 18(1)(a) and Sch 1 ('invention') ('s 6 of the Statute of Monopolies')), 'contrary to law' (Patents Act 1990 (Cth), s 50(1)(a); this only applies on 'examination' and 'modified examination': ss 45(1)(d) or 48(1)(c); Patents Regulations 1991 (Cth), r 3.18), and to certain foods and medicines (Patents Act 1990 (Cth), s 50(1)(b); this only applies on 'examination': ss 45(1)(d) or 48(1)(c); Patents Regulations 1991 (Cth), r 3.18); and 'innovation patents' - inventions that are 'generally inconvenient' (Patents Act 1990 (Cth), ss 18(1A), 18(1A)(a) and Sch 1 ('invention') ('s 6 of the Statute of Monopolies')), 'contrary to law' (Patents Act 1990 (Cth), s 101B(2)(d); this only applies on 'examination': s 101B(1)), and to certain foods and medicines (Patents Act 1990 (Cth), s 101B(4); this only applies on 'examination': s 101B(1)). Patents Act 1990 (Cth), s 18(2).

Patents Act 1990 (Cth), s 18(3). Other exclusions are inventions that are '[h]uman beings, and the biological processes for their generation' (Patents Act 1990 (Cth), s 18(2)), 'generally inconvenient' (Patents Act 1990 (Cth), ss 18(1), 18(1)(a) and Sch 1 ('invention') ('s 6 of the Statute of Monopolies')), 'contrary to law' (Patents Act 1990 $(\mathrm{Cth}), \mathrm{s} 101 \mathrm{~B}(2)(\mathrm{d})$. Notably, this only applies on 'examination': s $101 \mathrm{~B}(1))$, and to certain foods and medicines (Patents Act 1990 (Cth), s 101B(4). Notably, this only applies on 'examination': s 101B(1)). Macquarie Library (2006), p 38 ('animal'). See Woo-Suk Hwang's Application [2004] APO 24 (9 September 2004) at [9] (D Herald); see also Lawson (2009). Patents Act 1990 (Cth), s 3 and Sch 1 ('patent request'). Patents Act 1990 (Cth), s 3 and Sch 1 ('complete specification').

See Patents Act 1990 (Cth), s 3 and Sch 1 ('formalities check') and ss 52(1) and (2); Patents Regulations 1991 (Cth), r 3.2B. 
Commissioner assesses the complete specification, ${ }^{84}$ assessing the various threshold criteria on examination ${ }^{85}$ and re-examination. ${ }^{86}$ The Commissioner and others can seek the revocation of a granted innovation patent either by the Commissioner ${ }^{87}$ or in proceedings ${ }^{88}$ including as a cross-claim to infringement. ${ }^{89}$ A part of the assessment at examination, opposition and revocation is whether the alleged invention is appropriate subject-matter. ${ }^{90}$

In addition to the 'manner of manufacture' threshold, ${ }^{91}$ the Patents Act expressly excludes 'plants and animals, and the biological processes for the generation of plants and animals' unless they are 'a microbiological process or a product of such a process'. ${ }^{92}$ The meaning of the terms 'plants' and 'animals' in this provision remains uncertain. The extrinsic materials, remaining debate in Parliament and the associated extrinsic materials provided no further clues to what the terms 'plant' and 'animal' might mean. ${ }^{93}$ The section 18(3) exclusion has, however, been interpreted by IP Australia as having some relationship to the term 'plant' in the PBR Act so as avoid an overlap between PBRs and innovation patents. ${ }^{94}$ The result has been to allow the innovation patenting of microorganisms ${ }^{95}$ and

Patents Act 1990 (Cth), ss 101A and 101B(1) ('examination'), $101 \mathrm{G}$ ('re-examination') and $101 \mathrm{~N}(3)$ 'opposition').

Patents Act 1990 (Cth), s 101B(1) ('examination').

86

Patents Act 1990 (Cth), s 101G(2) ('re-examination').

Patents Act 1990 (Cth), ss 101F (after 'examination'), 101J (after 're-examination') and $101 \mathrm{~N}$ ('opposition').

Patents Act 1990 (Cth), s 138 ('revocation in circumstances other than surrender'). Notably the patent holder can also seek revocation on surrender of the patent: s 137 ('revocation on surrender').

Patents Act 1990 (Cth), s 121(1) ('cross-claim to infringement').

See Patents Act 1990 (Cth), ss 101B(2)(b) ('examination'), 101M(b) ('opposition') and s 138(3)(b) ('revocation in other circumstances'). Notably, 're-examination' is confined to the thresholds of 'novel' and 'innovative step': s 101G(3).

See Patents Act 1990 (Cth), ss 18(1A) and 18(1A)(a).

Patents Act 1990 (Cth), ss 18(3) and (4).

See Advisory Council on Intellectual Property (2004); Commonwealth (2000), p 18584; Explanatory Memorandum (Revised) (2000), p 10.

4 IP Australia (2010a), [2.31.4.6]. The veracity of this proposition is uncertain, as the legislation, the extrinsic materials (such as the Explanatory Memorandum) and the parliamentary debate do not address this matter, although the proposition has been made in subsequent reviews: see, for example, Advisory Council on Intellectual Property (2008), p 29. See also Advisory Council on Intellectual Property (2004), pp 31-34. Notably, this distinction has been made in other jurisdictions, albeit in dealing with the overlap of 'plant variety' rather than 'plant': see Plant Bioscience/Broccoli T0083/05(2007) 12 Official Journal of the European Patent Office 644 at 653-654; Novartis/Transgenic plant G01/98 [2000] EPOR 303 at 310 and 316-18 (addressing the dual protection of plant varieties under the European Patents Convention, Art 53(b)).

This includes 'bacteria, protozoans, bacteroids, mycoplasmas, viroids, bacteriophages and viruses per se': IP Australia (2010a), [2.31.4.6]. Notably, the actual meaning of 'microorganisms' as used by IP Australia is unclear as many, many organisms that might 
microbiological processes, ${ }^{96}$ while excluding 'animals' and 'plants' (embracing 'all fungi (including yeasts and moulds) and algae') ${ }^{97}$ such as: 'genetically modified whole plants, plants produced by cross-breeding of one strain with another strain, or selection of a plant from a range of plants'; 'genetically modified whole animals (including human beings), animals produced by cross-breeding of one strain with another strain, or selection of an animal from a range of animals'; 'seeds of plants, plant tissue cultures, or any matter that could give rise to a plant'; and 'animal embryos or fetuses, zygote, or any matter or group of cells, that could give rise to an animal' ${ }^{98}$

A further requirement of the Patents Act is to describe an invention fully ${ }^{99}$ so that the nature of the invention is apparent from reading the whole

otherwise be considered 'plants' and 'animals' (and within the Kingdoms Animalia and Plantae) are also small in size (in fact, microscopic), perhaps introducing a size standard for the terms 'plant' and 'animal'. For example, a photosynthesising blue-green algae could be characterised as a 'plant' because of its photosynthesising capacity while also being characterised as a 'Monera' and 'micro-organism' outside the meaning of 'plant' (as in 'Planta'): see Whittaker (1969), p 154. Further confusion arises as the Patents Act, s 41(1) provides for a deposit requirement to satisfy the s 40(2)(a) description standard, and might be satisfied by any materials accepted by a proper depositary authority: see IP Australia (2010a), [2.7.1]. In practice, depositary authorities have accepted non-microorganisms such as algae, protozoa, eukaryotic cells and tissues, cell lines, hybridomas, plant tissue cells, lichens and plant spores, and other biological materials such as plasmids, viruses and prions: see World Intellectual Property Organisation (2010), Part II, pp 10177; IP Australia (2010b), pp 1-2. The only assistance in the distinguishing between 'plants' and 'animals' excluded from innovation patents and those materials that are acceptable to a depositary authority might be the practical requirements of the depositary authority: see, for examples, Lady Mary Fairfax CellBank Australia (2009); National Measurement Institute (2008); American Type Culture Collection (2008). Interestingly, depositary authorities require, as a part of the process of accepting and maintaining a biological organism deposit, some form of taxonomic designation of the organism (these names might also be expected to, and as a matter of practice do, conform to naming codes such as the International Code of Botanical Nomenclature, the International Code of Nomenclature for Cultivated Plants, and so on): see, for example, Lady Mary Fairfax CellBank Australia (2009), p 2; National Measurement Institute (2008), p 3; American Type Culture Collection (2008), p 1. See also Budapest Treaty, Art 12; Budapest Treaty Regulations, r 6.1(b).

Such as 'preparation of cheese, wine making, brewing and industrial processes involving the use of microorganism such as microbial bleaching, leaching of ores using microorganism', 'the use of enzymes derived from microorganisms for the preparation of, for example cheese or, detergents comprising protease', 'the use of yeast, fungi or moulds for the production of useful products, for example penicillin, enzymes, fermented meats, or industrial alcohol and the products produced by such use' and 'the use of viruses in the preparation of vaccines, for example': IP Australia (2010a), [2.31.4.6]. See also IP Australia (2010b), pp 4-5; Explanatory Memorandum (Revised) (2000), p 10.

IP Australia (2010a), [2.31.4.6]. 
specification, including the claims ${ }^{100}$ to a person skilled in the relevant $\operatorname{art}^{101}$ at the date the Patents Acts statutory monopoly takes effect. ${ }^{102}$ In addition to describing the features of the invention, the description of a plant or animal will generally also set out 'the name of the new [plant or animal] variety'. ${ }^{103}$ The naming standards relevant to a person skilled in the art are those set out in the various naming codes such as the International Code of Botanical Nomenclature, the International Code of Nomenclature for Cultivated Plants, and so on. In short, this analysis shows that, like the PBR Act - although perhaps not so boldly - biological organisms under the Patents Act are also conceived in the language and application of taxonomy and naming codes. The next issues are whether taxonomy and the naming codes are suitable means of conceiving biological organisms for the purposes of the PBR Act and the Patents Act.

\section{Taxonomic Conceptions}

At it most skeletal, and returning to basic statutory interpretation, the $P B R$ Act requires the subject-matter be a 'plant' that is defined to include 'fungi' and 'algae', and this subject-matter is excluded as a matter of practice from an 'innovation patent' under the Patents Act. ${ }^{104}$ An 'innovation patent' under the Patents Act also excludes 'animals'. ${ }^{105}$ Essentially, 'algae', 'animals', 'fungi' and 'plants' (excluding 'fungi' and 'algae') are the uncertain terms. A dictionary definition suggests the meaning of these terms: 'algae' means 'chlorophyll-containing plants belonging to the phylum Thallophyta, comprising seaweeds and various freshwater forms and varying in form and size ... They constitute a subphylum, the Algae'; 'animal' means 'any living thing that is not a plant, generally capable of voluntary motion, sensation, etc' and 'any animal other than a human'; 'fungus' means 'any of the Fungi, a group of thallophytes including the mushrooms, moulds, mildews, rusts, smuts, etc, characterised chiefly by absence of chlorophyll and which subsist upon dead or living organic matter'; and 'plant' means 'any member of the vegetable group of living organisms'. ${ }^{106}$ These definitions all assert a

100 Kimberly-Clark Australia Pty Ltd v Arico Trading International Pty Ltd (2001) 207 CLR 1 at 12-13 (Gleeson CJ, McHugh, Gummow, Hayne and Callinan JJ).

101 Kimberly-Clark Australia Pty Ltd v Arico Trading International Pty Ltd (2001) 207 CLR 1 at 16 (Gleeson CJ, McHugh, Gummow, Hayne and Callinan JJ). This requirement will also be satisfied if a skilled person can 'easily rectify the mistakes and can readily supply the omissions': AMP Inc v Utilux Pty Ltd (1971) 45 ALJR 123 at 128 (McTiernan J) citing No-Fume Ltd v Frank Pitchford \& Co (1935) 52 RPC 231 at 243 (Romer LJ).

102 Rescare Ltd v Anaesthetic Supplies Pty Ltd (1992) 111 ALR 205 at 223 (Gummow J). Although where 'micro-organisms' are deposited this date may be earlier than the date the complete specification is lodged: see Patents Act 1990 (Cth), s 6.

103 See IP Australia (2010a), [2.7.2.1].

104 See Plant Breeder's Rights Act 1994 (Cth), s 3(1); Patents Act 1990 (Cth), s 18(3).

105 See Plant Breeder's Rights Act 1994 (Cth), s 3(1); Patents Act 1990 (Cth), s 18(3).

106 Macquarie Library (2006), pp 24 ('algae'), 38 ('animals'), 477 ('fungi') and 922 ('plants'). 
grouping of organisms according to characteristics, which is the essence of taxonomy, and this is consistent with the taxonomic language used in both the PBR Act and the Patents Act. The issue for our purposes is whether taxonomy can usefully distinguish and bound 'algae', 'animals', 'fungi' and 'plants'.

Modern taxonomy traces its origins to concerns that biological organisms should be identified distinctly by a name so that a decontextualised identifier of a specific kind of organism would allow global exchange. ${ }^{107}$ The approach was to classify organisms according to similarities following a strict hierarchy based on increasingly shared characters, and characters that distinguish between sub-groupings ('boxes within boxes'). ${ }^{108}$ Over time, the classification of the variation and complexity of biological organisms has evolved to a consensus model that recognises a hierarchy of relationships - a hierarchy from gross similarity to the minutia of difference: Domain, Kingdom, Divisions (Phylum), Classes, Orders, Families, Genera, Species, and then a plethora of lower rank taxa (including sub-species, varieties, forms, cultivars, and so on). ${ }^{109} \mathrm{~A}$ unifying theme has been the evolutionary idea of organisms having a (single) common ancestry (the 'Tree of Life'), with the apparent diversity reflecting adaptive mechanisms first detailed by Darwin and subsequently synthesised to deal with genetics (the New Synthesis or neo-Darwinism). ${ }^{110}$ These classifications are linked to co-evolving naming codes (albeit 'divorcing the name from diagnosis and minimizing classification') $)^{111}$ for organisms traditionally treated as animals (International Code of Zoological Nomenclature), organisms traditionally treated as plants (International Code of Botanical Nomenclature and supplementary codes), bacteria (International Code of Nomenclature of Bacteria) and viruses (International Code of Virus Classification and Nomenclature and various other contested proposals). The significance of the co-evolving naming codes is that each requires a description or diagnosis of the organism in the context of a taxonomic classification to differentiate the named entity from other taxa. ${ }^{112}$ For our

\footnotetext{
107 See, for example, Müller-Wille (2003), pp 162-66 and the references therein.

108 Although this was itself a controversial proposition - see, for example, McOuat (2006) and the references therein.

109 See, for examples, Woese (2000); Walsh and Doolittle (2005); Simpson and Roger (2004), and so on. See also, for example, International Code of Botanical Nomenclature, Art 3.1 ('kingdom (regnum), division or phylum (division, phylum), class (classis), order (ordo), family (familia), genus (genus) and species (species)'). Although the number and content of taxa do remain contested - see, for example, Roger and Hug (2006); Rappé and Giovannoni (2003); Lawrence et al (2002); Cavalier-Smith (1998), and so on.

110 See, for an elegant synthesis, Gould (2002). Comparative and functional genomics is, however, challenging this evolutionary conception of organism relationships according to the 'Tree of Life' - see, for example, Koonin (2009); Lynch (2007).

$111 \quad$ Nicolson (1991), p 33.

112 See, for example, International Code of Zoological Nomenclature, Art 13.1; International Code of Botanical Nomenclature, Art 32.1; International Code of Nomenclature of
} 
purposes, it is the classification of the rank above Genera that is useful for defining 'plants' (including 'fungi' and 'algae') under the PBR Act and 'plants' and 'animals' under the Patents Act. ${ }^{113}$

The most widely accepted scheme of classification above the rank of Genera recognises five kingdoms (Animalia, Plantae, Fungi, Protista and Monera). ${ }^{114}$ Within this scheme, the groupings of 'animals', 'plants' (not including 'fungi' and 'algae') and 'fungi' appear to correspond neatly with the kingdoms Animalia, Plantae and Fungi respectively. ${ }^{15}$ There remain, however, further proposals for even more groupings at the kingdom taxon showing that taxonomy itself remains contested. ${ }^{116}$ The six-kingdom scheme (Animalia, Plantae, Fungi, Protozoa, Chromista and Bacteria) also appears to correspond neatly with the kingdoms Animalia, Plantae and Fungi for the groupings of 'animals', 'plants' (not including 'fungi' and 'algae') and 'fungi' respectively, although the respective contents of the six kingdoms do not correspond with the content of the earlier five kingdoms. ${ }^{117}$ This suggests that limiting the meaning of the terms according to the organisms within the kingdom taxon (and according to the five- or six-kingdom classification) may usefully distinguish the biological organisms defined as 'plants' (not including 'fungi' and 'algae') and 'fungi' that are included within the subject-matter of the PBR Act, and 'animals' and 'plants' excluded from an 'innovation patent' under the Patents Act. ${ }^{118}$ The immediate problem would be that a particular organism might fall within a different kingdom, depending on the choice of the five- or six-kingdom scheme. ${ }^{119}$

The more acute problem arises, however, for 'algae' that are classified in different kingdoms (according to the five-kingdom classification),

Bacteria, Rule 27(2); International Code of Virus Classification and Nomenclature, Rule 5.

113 Perhaps importantly, a 'taxon' is an artificial designation of degrees of similarity ('boxes within boxes') adopted by taxonomists, and there is no equivalence between a taxon applied to distinguishable taxa at that level. In other words, the taxa applied to domestic cats (Felis catus L) bear no resemblance to the degrees of similarity of taxa applied to mangoes (Mangifera indica L). See also de Queiroz and Cantino (2001).

114 See Whittaker (1969). Notably, Monera might be split into the Eubacteria and the Archaebacteria in a six-kingdom classification: see Woese and Fox (1977). There might be a growing consensus for groupings within the five-kingdom classification (Animalia, Plantae, Fungi and Protista) to accord with a system of six 'supergroups' (Amoebozoa, Chromalveolata, Excavata, Opisthokonta, Plantae and Rhizaria) - see, for example, Wegener Parfrey et al (2006).

115 See Whittaker (1969), pp 154-55 and 157.

116 See, for example, Cavalier-Smith (1981, 1998); see also Mayr (1990); Corliss (1984).

117 See Cavalier-Smith (1998).

118 See Plant Breeder's Rights Act 1994 (Cth), s 3(1); Patents Act 1990 (Cth), s 18(3).

119 For example, the six-kingdoms classification includes brown algae in Kingdom Chromista (see Cavalier-Smith 1998, p 250) while the five-kingdom classification includes brown algae in Kingdom Plantae (Whittaker 1969, p 154). So, depending on the choice of classification, brown algae might be classified as 'plants' in Kingdom Plantae. 
depending on the particular characters: blue-green algae in Monera; golden algae in Protista; red, green and brown algae in Plantae. ${ }^{120}$ Further, the dictionary reference for 'algae' to 'chlorophyll-containing plants belonging to the phylum Thallophyta', set out above, adds further confusion as the term 'Thallophyta' is not defined in the dictionary, and probably refers to a defunct taxon comprising a heterogeneous assemblage of flowerless and seedless organisms including algae, bacteria, fungi and lichens. Thus, taxonomy according to the kingdom taxon does not usefully distinguish the biological organisms defined as 'algae' that are included within the subjectmatter of the PBR Act (and possibly excluded from an 'innovation patent' under the Patents Act). ${ }^{121}$ The term 'algae' may, however, be usefully distinguished according to the five-kingdom classification at the division (or phylum) taxon: blue-green algae in Phylum Cyanophyta (in Kingdom Monera); golden algae in Phylum Chrysophyta (in Kingdom Protista); red, brown and green algae in Phylum Rhodophyta, Phaeophyta and Chlorophyta (in Kingdom Plantae). ${ }^{122}$ Similarly, according to the six-kingdom classification, 'algae' may usefully be distinguished at the division (or phylum) taxon: blue-green algae in Phylum Cyanobacteria (in Kingdom Bacteria); golden algae and brown algae in Phylum Ochrophyta (in Kingdom Chromista); red and green algae in Phylum Rhodophyta and Chlorophyta respectively (in Kingdom Plantae). ${ }^{123}$

While the five- and six-kingdom classifications remain popular, they remain contested, especially with the development of modern genetics and molecular biology. As a consequence of the considerable diversity of organisms that have evolved over a very long timespan, any classification scheme naming groupings will impose arbitrary distinctions on the continuum of natural variation. There are two predominant metaclassification methodologies that have developed. One focuses on grouping organisms according to all anatomical and bio-molecular similarities (the 'traditional' or pre-Darwin Linnaean system of taxonomy now accommodating the principle of common descent) (the five- and sixkingdom classifications); the other focuses on grouping organisms according to some anatomical and bio-molecular similarities of relatedness (also called phylogenetics - the post-Darwin system based on the principle of common descent). ${ }^{24}$ The difference in these meta-methodologies is essentially about

120 See, for example, Whittaker (1969), p 154.

121 See Plant Breeder's Rights Act 1994 (Cth), s 3(1); Patents Act 1990 (Cth), s 18(3). For this author, the practice of IP Australia of interpreting the Patents Act 1990 (Cth) subject to the Plant Breeder's Rights Act 1994 (Cth) (see IP Australia (2010a), [2.31.4.6]) is not supported by any authority, and the justification for this distinction in the European Patent Convention, Art 53(b) jurisprudence reflects a particular development in that jurisdiction (see Novartis/Transgenic plant G01/98 [2000] EPOR 303 at 314-17).

122 See Whittaker (1969), p 154.

123 See Cavalier-Smith (1998), pp 218, 250 and 252.

124 See, for example, de Queiroz and Gauthier (1992) and the references therein. Another formulation of these different meta-classification methodologies is that the 'traditional' 
the weight given to the anatomical and bio-molecular characters, the latter phylogenetics giving greater weight to shared derived (synapormophy) characters (and excluding primitive features or plesiomorphy), and based on the principle of common descent (evolution) as opposed to mere shared characters. ${ }^{125}$ The consequence for taxonomy is that groupings based on the 'traditional' or pre-Darwin Linnaean system of taxonomy mandate that organisms be assigned to the kingdom, division/phylum, order, family, genus taxa, implying relatedness that may not actually exist. ${ }^{126}$ The result of then adopting refinements on the basis of phylogenetics within the traditional taxonomy has been an ongoing development of uncertain classifications ('taxon stability' and the quest for mono-phylogeny). ${ }^{127}$ This uncertainty is a direct consequence of the recent developments in comparative and functional genomics that now challenge the neat (evolutionary) conception of organismal relationships according to common ancestry and the 'Tree of Life', and demonstrate that non-adaptive processes are significant. ${ }^{128}$ Importantly, while these developments do not challenge the proposition that extant life evolved from a single common ancestor, they do make tracing the particular steps of evolution and differentiation extraordinarily difficult, ${ }^{129}$ and open the likely taxonomy for the two predominant meta-classification methodologies, and the merging of information resulting from these methodologies, to considerable differences and controversies. ${ }^{130}$ The result has been in recent decades a proliferation of taxonomies: three domains; ${ }^{131}$ five kingdoms $;{ }^{132}$ six kingdoms; $;{ }^{133}$ six supergroups, ${ }^{134}$ and so on. ${ }^{135}$ While the five-kingdom classification appears to

(pre-Darwin Linnaean) system considers all similarities as meaningful, while phylogenetics (post-Darwin) only takes account of some similarities associated with relatedness (shared derived characters or synapomorphies) and expressly excludes retained primitive characteristics (or plesiomorphy).

125 This is an ongoing controversy, especially with determining primitive versus derived character states and the weight to be given to sequence information - see, for example, Schwartz and Maresca (2006). Thus, for example, a primitive character will be excluded from a phylogenetic analysis while being given equal weighting in a traditional analysis.

126 See, for example, Wiley (1979); Griffiths (1976).

127 See, for example, de Queiroz and Gauthier (1992), pp 454-57 and the references therein.

128 See, for example, Brown (2003). Notably, comparative analysis of genomes suggests that there may even be horizontal gene transfer between Domains - see, for example, Nelson et al (1999); see also Lynch (2007).

129 See, for example, Mat et al (2008); Mushegian (2008). See also Becerra et al (2007).

130 See, for example, Embley and Martin (2006) (in particular, compare references 57-61 and 62-64 about the origins of mitochondria). For an overview of the contested values in recent taxonomy, contrast, for example, Blaxter (2004) and Wheeler (2004), pp 576-78.

131 See Woese (2000); Woese et al (1990).

132 See Whittaker (1969).

133 See Cavalier-Smith (2004). See also Balch et al (1977).

134 See, for example, Wegener Parfrey et al (2006). Notably, this 'super group' classification system has not gained consensus support, although some of the details about relationships 
remain the consensus, it is being challenged by these other schemes so that taxonomy itself cannot be said to be stable. Rather, taxonomy continues to develop, taking advantage of new technological developments and the plethora of available (genetic) information.

Despite these differences and controversies about methodologies and the resulting information, the composite outcomes from these methodologies in the context of kingdom classifications may only have significant impacts for Kingdoms Animalia, Plantae and Fungi in the fine distinctions at the lower taxa of genus, species and below, as they appear to be relatively stable at the higher level taxa of kingdoms ${ }^{136}$ and domains. ${ }^{137}$ The broader groupings of organisms assigned to Kingdoms Protista (alternatively comprising Archezoa, Protozoa and Chromista) and Monera (alternatively comprising Eubacteria and Archaebacteria), however, appear more likely to be open to changes, given the potentially considerable diversity of organisms presently grouped in these kingdoms. ${ }^{138}$ More significantly, the place of 'algae' remains uncertain: ${ }^{139}$ according to the five-kingdom classification, the bluegreen algae are in Kingdom Monera, the golden algae in Protista and the red, green and brown algae in Plantae; ${ }^{140}$ according to the six-kingdom classification (Animalia, Plantae, Fungi, Bacteria, Protozoa and Chromista) the additional Kingdom Chromista includes most of the algae (principally the golden and brown algae), although various algae are classified within Kingdoms Plantae (some of the red and green algae) and Protozoa (some of the green algae) ${ }^{141}$ In contrast, however, the six super-group classification scheme relying heavily on phylogenetics challenges the existing kingdoms, recognising that the traditional Kingdoms Animalia, Fungi and Plantae arise within monophyletic protist lineages, so that Animalia and Fungi appear to fall within the Opisthokonta super-group, and the Plantae within the Charophyta super-group. ${ }^{142}$ While the super-group classification has revealed

are being considered and addressed - see, for example, Burki et al (2007); Hackett et al (2007). See also Keeling et al (2005); Adl et al (2005).

135 See, generally, Walsh and Doolittle (2005); Allers and Mevarech (2002).

136 See, for example, Cavalier-Smith (1998). Notably, however, some instability remains - as, for example, Cavalier-Smith's kingdom classifications proposed that Kingdom Plantae include all the Viridaeplantae (green plants based on the monophyletic symbiogenetic origin of chloroplasts) (pp 207-9). See also Cavalier-Smith (1981). See Woese (2000); Woese et al (1990).

138 See, for example, Cavalier-Smith (2004). Although Cavalier-Smith argues that, even among the protists, "there may be very few, if any, previously unknown protest phyla and no "new kingdoms" - remaining to be "discovered" (p 1260). See also, for example, Berney et al (2004).

139 A part of the taxonomic problem with 'algae' is their contested origins - see, for example, Bhattacharya et al (2004).

140 See, for example, Whittaker (1969), p 154.

141 See Cavalier-Smith (1998), pp 232 (Kingdom Protozoa), 250 (Kingdom Plantae) and 251 (Kingdom Chromista).

142 See, for example, Adl et al (2005). 
problems for the more traditional kingdom classification, the details of super-groups remain to be settled, ${ }^{143}$ and without greater stability, consensus and its usefulness for the PBR Act and the Patents Act are uncertain. ${ }^{144}$ Importantly, and as a generalisation, stability is not the objective of taxonomy: 'But stability is not a primary value in classification. If it were, we should rigidly retain the oldest classification irrespective of how bad it is!' ${ }^{145}$ Whether de-linking conceptions of kingdoms from schemes of classification and the likely effect of the super-group classification on the future of kingdoms remains unclear. Perhaps an outcome will be that the super-groups resolve into more refined (and perhaps additional) kingdoms to maintain current traditions and the utility of phenotypically similar groupings such as Animalia, Fungi and Protozoa for broader scientific endeavors of classification and beyond mere phylogeny (relatedness). ${ }^{146} \mathrm{In}$ short, this analysis shows that taxonomy could be useful in conceiving biological organisms for the purposes of the PBR Act and the Patents Act; however, there remains instability and uncertainty about which taxonomy to apply.

\section{Nomenclature Conceptions}

Irrespective of the taxonomic choices, the naming of the organism (nomenclature) according to the naming codes might provide an alternative to determine whether an organism is suitable subject-matter. ${ }^{147}$ Importantly, the naming codes expressly exclude directly linking naming to taxonomy, so as to separate the name of the organism from the characters of the organism. ${ }^{148}$ Thus, for example, the International Code of Zoological Nomenclature expressly provides:

143 See, for examples, Roger and Simpson (2009); Yoon et al (2008).

144 Although this is perhaps changing rapidly as areas of contention are settled - see, for example, Keeling et al (2005); Steenkamp et al (2005); Philippe et al (2004).

145 Cavalier-Smith (1998), p 213.

146 Cavalier-Smith (1998), p 213.

147 While naming codes may not be a direct proxy for taxonomy, there is a measure of correspondence: Cavalier-Smith's revised six-kingdom scheme posits '[t]he two zoological kingdoms (Protozoa, Animalia) are subject to the Zoological Code of Nomenclature, the single bacterial kingdom to the Bacteriological Code of Nomenclature, and the three botanical kingdoms (Plantae, Fungi, Chromista) to the Botanical Code of Nomenclature': Cavalier-Smith (1998), p 259.

148 See International Code of Zoological Nomenclature, Preamble; International Code of Botanical Nomenclature, Preamble 1 and 9; International Code of Nomenclature of Bacteria, General Consideration 4. In contrast, the classification and naming of 'viruses' coincide: International Code of Virus Classification and Nomenclature, Rule 1. Further, the International Code of Nomenclature for Cultivated Plants perhaps reflects the ambiguity in this strict separation between naming and taxonomy: 'The current edition of the International Code of Botanical Nomenclature provides for names in Latin form for taxonomic units of organisms traditionally treated as plants (including fungi) whose naming is not governed by this Code.' Brickell et al (2004), p 2. See generally Gledhill (2008); Spencer et al (2007). 
The objects of the Code are to promote stability and universality in the scientific names of animals and to ensure that the name of each taxon is unique and distinct. All its provisions and recommendations are subservient to those ends and none restricts the freedom of taxonomic thought or actions. ${ }^{149}$

Further, the naming codes have developed through practice and apply to organisms treated as the subject of zoology (International Code of Zoological Nomenclature), botany (International Code of Botanical Nomenclature and supplementary codes), bacteriology (International Code of Nomenclature of Bacteria) and virology (International Code of Virus Classification and Nomenclature and various other contested proposals). The result has been that the International Code of Zoological Nomenclature applies broadly to 'animals' referring to 'the Metazoa and also to protistan taxa when workers treat them as animals', ${ }^{150}$ the International Code of Botanical Nomenclature applies broadly to 'organisms traditionally treated as plants ... [such as] ... blue-green algae (Cyanobacteria); fungi, including chytrids, oomycetes, and slime moulds; photosynthetic protists and taxonomically related non-photosynthetic groups' ${ }^{151}$ and so on. ${ }^{152}$ In practice, however, choosing a name requires an election to apply a particular naming code according to epistemic conventions consistent with the naming codes' subject-matters - so botanists would consider the organism something within their realm and within the naming codes applying to their subject of study. ${ }^{153}$ Some measure of consensus and review is applied as a name only becomes formally accepted following 'publication'. ${ }^{154}$ The effect of the naming codes is that zoological naming is applied to 'animals' and botanical naming is applied to 'plants' (including 'fungi' and 'algae'), broadly corresponding with the zoology and botany naming codes. There are some overlaps that could create some confusion (especially for 'ambiregnal organisms' - those covered by multiple codes), although again some measure of consensus and review is applied through publication and acceptance by the epistemic conventions. As a generalisation, a name is a binary combination consisting

149

International Code of Zoological Nomenclature, Preamble, emphasis added.

International Code of Zoological Nomenclature, Art 1.1.1.

International Code of Botanical Nomenclature, Preamble 7.

See, for example, International Code of Nomenclature of Bacteria, General Consideration 1; International Code of Virus Classification and Nomenclature, Rules 1 and 3.

On the use of naming codes and intellectual property see Sherman (2008), pp 566-75.

See International Code of Zoological Nomenclature, Arts 8 and 9; International Code of Botanical Nomenclature, Arts 29-50; International Code of Nomenclature of Bacteria, Rules 23a-32b; International Code of Virus Classification and Nomenclature, Rules 5 and 19. As a generalisation, 'publication' requires the name to appear in some publicly distributed material form such as a journal, book, magazine, pamphlet and the like, but not by an announcement at a public meeting, label on a public herbarium specimen, printing in a confidential trade list and the like - see, for example, International Code of Nomenclature for Cultivated Plants, Arts 6 and 22. 
of a genus followed by a species - for example, Cornus sanguinea ${ }^{155}$ - with taxonomy informing the choices of names:

The principal ranks of taxa in descending sequence are: kingdom (regnum), division or phylum (divisio, phylum), class (classis), order (ordo), family (familia), genus (genus), and species (species). Thus, each species is assignable to a genus, each genus to a family, etc. ${ }^{156}$

The consequence is that there is a measure of consistency between taxonomy and the choice of naming code so that 'animals' might usefully be conceived as those that are named according to the International Code of Zoological Nomenclature, and 'plants' (including 'fungi' and 'algae') conceived as those that are named according to the International Code of Botanical Nomenclature and supplementary codes.

In summary so far, taxonomy may provide a useful framework for determining whether or not a biological organism is, or is not, subject-matter for the purposes of the PBR Act and the Patents Act. The naming codes may not, however, be a suitable proxy for taxonomy given their broad practical reach and their (apparent) disconnection (except for viruses) from taxonomy. The naming codes do, however, provide a broad conception of a biological organism classification that is consistent with taxonomy in the sense that these codes pre-suppose rank-based classifications - perhaps with the exception of the contested ambiregnal organisms. So the requirement in the $P B R$ Act that an application detail a 'name (including a synonym), in respect of a plant variety must comply with the International Code of Botanical Nomenclature and subsidiary codes' ${ }^{157}$ is a requirement, in effect, that the subject-matter be accepted within the realm of organisms covered by the International Code of Botanical Nomenclature and subsidiary codes. Similarly, while the Patents Act imposes no such formal naming requirements, ${ }^{158}$ even though there may be a direct proxy for deposited samples that require naming to be deposited, ${ }^{159}$ it seems very likely most biological organisms will have acquired a name in their development. These requirements assess the particular kind of biological organism:

the process of being given a name carries with it certain consequences. This is because by the time a plant is christened with a

155 International Code of Botanical Nomenclature, Art 23. See also International Code of Zoological Nomenclature, Art 5; International Code of Nomenclature of Bacteria, Rule 12a; International Code of Virus Classification and Nomenclature, Rule 2.

156 International Code of Botanical Nomenclature, Art 3.1. See also International Code of Zoological Nomenclature, Arts 4-6; International Code of Nomenclature of Bacteria, General Consideration 7; International Code of Virus Classification and Nomenclature, Rule 2.

157 See Plant Breeder's Rights Act 1994 (Cth), s 27(6).

158 The Patents Act 1990 (Cth), s 40(2)(a) description will generally require a name for the 'animal' or 'plant': IP Australia (2010a), [2.7.2.1].

159 See, for example, National Measurement Institute (2008), p 3; American Type Culture Collection (2008), p 1. 
name, the taxonomist (or in some cases a systematic biologist) will have described the plant's characteristics, assigned the plant a place within a family, explained its kinship with other plants of the same family, and shown how through some minute distinction, perhaps the veining on the leaf, the hairs on the stem, or habit of growth how the plant differs from other plants. ${ }^{160}$

The current naming codes (International Code of Zoological Nomenclature, International Code of Botanical Nomenclature and supplementary codes, International Code of Nomenclature of Bacteria, and Code of Virus Classification and Nomenclature and various other contested proposals) are presently weighted in favour of the grouping organisms according to the 'traditional' or pre-Darwin Linnaean system of taxonomy and any anatomical and bio-molecular similarities (and specifically to genera and species). ${ }^{161}$ Alternatives that address phylogenetics (and cover all organisms) are currently proposed with some effects for naming. ${ }^{162}$ Despite these alternative schemes, resolving differences using taxonomy and the related names for 'plants', 'animals', 'fungi' and 'algae' at higher level taxa of kingdoms and divisions (phyla) is likely to remain useful, while such distinctions at lower level taxa might not be so useful. ${ }^{163}$ To address these lower level taxa distinctions, other naming codes have been adopted to address the specifically different requirements of the organisms being distinguished. For example, for plants the International Code of Nomenclature for Cultivated Plants is directed to plants under cultivation, accepts the naming by the International Code of Botanical Nomenclature and merely adds extra parts of those names to differentiate lower level variations (below species taxon). ${ }^{164}$ Thus, for example, the taxonomic name (genus species) is complemented with a cultivar or group epithet: Fragaria ananassa 'Cambridge Favourite'. ${ }^{165}$

The increasing data from comparative and functional genomics is also likely to enhance the ability to make distinctions, but also to confuse possible distinctions by identifying horizontally transferred characters that might be attributed to other kingdoms. ${ }^{166}$ Perhaps importantly, while the effects of phylogenetics (and the plethora of comparative and functional

160

Sherman (2008), p 572.

See, for example, Cavalier-Smith (1998), pp 203 and 213-14. This also flows through to the uses of language in the naming schemes: see de Queiroz and Gauthier (1992), pp 45253.

Essentially, the clade is named independently of the taxonomic rank - see, for example, Laurin and Cantino (2007); Kuntner and Agnarsson (2006). See also www.ohio.edu/phylocode/preface.html (PhyloCode).

See, for example, Koonin (2007); Wolf et al (2002).

International Code of Nomenclature for Cultivated Plants, Principle 2.

See International Code of Nomenclature for Cultivated Plants, Art 7.1.

On the likely effects of comparative and functional genomics, see Koonin (2009). 
genomics information) have also been to spawn new proposals for naming, ${ }^{167}$ these have not gain broad consensus, and at best a compromise with existing naming codes seems likely. ${ }^{168}$ Thus:

Linnaean nomenclature is stable enough to say what we know, flexible enough to accommodate what we learn; independent of specific theory, yet reflective of known empirical data; compatible with phylogenetic theory, but not a slave to it; particular enough for precise communication, general enough to reflect refuted hypotheses. ${ }^{169}$

In the context of the PBR Act and the Patents Act, there is the useful assignment of names according to a naming code that correspond with zoological, botanical, bacterial and viral organisms. This is essentially a choice, with those describing themselves as zoologists, botanists, bacteriologists and virologists deciding which naming code to use. The result, however, is that naming codes also provide a useful means of conceiving of biological organisms for the purposes of the PBR Act and the Patents Act, and this is generally informed by taxonomy. The significant caution must be the apparent arbitrariness of naming codes (demonstrated by the ambiregnal organisms) and their application according to epistemic conventions.

\section{Conclusions}

Final and absolute certainty about the meaning of the terms 'plants' (including 'fungi' and 'algae') and 'animals' for the purposes of the PBR Act and the Patents Act is unlikely. This article demonstrates, however, that adopting some of the conceptions from taxonomy may usefully clarify the scope of included and excluded biological organisms, and that naming codes add to this by usefully distinguish variation that might not be apparent from the taxonomic descriptions. In short, the analysis shows that taxonomy and naming codes provide a avenue of resolution to the uncertainty, though there are some further problems that emerge from seeking a final solution to definition through taxonomy and naming codes.

The analysis of the instability in taxonomy suggests that while taxonomy might usefully clarify the scope of included and excluded biological organisms defined as 'plants', 'animals', 'fungi' and 'algae', the specific content of those terms changes over time as taxonomy is inherently contested and developing. Put simply, the base unit of taxonomy is the taxon, and this is at best a hypothesis: "names are convenient shorthand representations of scientific hypotheses, and as such should be as volatile as

167 See PhyloCode: de Queiroz (2007); Dayrat (2005). See also Bertrand and Härlin (2006); Artois (2001); Härlin (2003); Bryant and Cantino (2002).

168 See, for example, Kuntner and Agnarsson (2006). See also Laurin (2008); Fitzhugh (2008); Stevens (2006).

169 Wheeler (2004), pp 577-78. 
hypotheses in any other field - proposed, used, modified and then perhaps discarded as evidence dictates' ${ }^{170}$ To address this particular problem, IP Australia or the Parliament could mandate the particular taxonomy, updating the conceptions of 'plants', 'animals', 'fungi' and 'algae' to reflect the developing consensus. Alternatively, the assessment might be left, like many other thresholds under the PBR Act and the Patents Act, to be made at the time the application is lodged according to a 'priority date'. ${ }^{171}$ In cases of contested and challenged PBRs and patents, this undoubtedly will include expert evidence about the appropriate taxonomy at that 'priority date', ${ }^{172}$ and be finally determined by a judge in a federal court. ${ }^{173}$ While not an entirely satisfying conclusion, because there remains some uncertainty about the threshold conception, the likelihood of difficult cases seems remote given that there will have been some consensus among botanists, zoologists, virologists, and so on about the lineage of the organism reflected in resolving their classifications and names within the context of their development that will be apparent at the time the application is lodged. ${ }^{174}$ In other words, the threshold conception of biological organisms may be fuzzy, but there is likely to be consensus determinable by a judge based on expert evidence from those making and using the alleged plant variety or invention through the combined operation of taxonomy and naming. ${ }^{175}$ In this sense, taxonomy and the naming codes do not provide a definitive standard, though they may be a useful proxy for reducing organisms to the objects of law.

A more pressing problem - and perhaps the biggest challenge to a taxonomic conception of biological organisms for intellectual property - is the advent of artificial, ${ }^{176}$ reconstituted ${ }^{177}$ and merged biological organisms. ${ }^{178}$

170 Thiele and Yeates (2002), p 337. Notably, there are suggestions for a firmer and more centralised approach for a consistent taxonomy - see, for example, Godfray et al (2007). Again, however, there remains the problem that there is no comprehensive coverage of the names already in use and their significant definitive characteristics - see, for example, Greuter (2000), pp 137-38.

171 The priority date: Plant Breeder's Rights Act 1994 (Cth), s 28; Patents Act 1990 (Cth), s 43.

172 See Plant Breeder's Rights Act 1994 (Cth), s 77(1); Patents Act 1990 (Cth), ss 101B(2)(b) ('examination'), $101 \mathrm{M}(\mathrm{b})$ ('opposition') and 138(3)(b) ('revocation in other circumstances').

173 Plant Breeder's Rights Act 1994 (Cth), s 56; Patents Act 1990 (Cth), s 154; Federal Court of Australia Act 1976 (Cth), s 19. The Federal Court's decision is then subject to appeal to the Full Federal Court (Federal Court of Australia Act 1976 (Cth), s 24(1)(a)) and then to the High Court if special leave to appeal is granted (Federal Court of Australia Act 1976 (Cth), s 33).

174 See Sherman (2008), pp 565-66.

175 This conclusion is also consistent with the proposition that the process of naming consequently means that the organism is appropriately identified and characterised: see Sherman (2008), p 572.

176 For example, an autonomous bacterium with a 21 (rather than 20) amino acid genetic code: Mehl et al (2003). See also Lartigue et al (2009). See generally Kaiser (2007).

177 For example, a reconstructed influenza virus strain: Tumpey et al (2005). 
These are organisms with additions and subtractions to their compositions, such as genetic materials (DNA, RNA and amino acids) or tissues, following the technical intervention of humans, with characteristics that are unique and that have surmounted the evolved barriers to reproduction. For example, the artificial insertion and deletion of DNA resulting in the presence or absence of a particular characteristic (a classic genetically modified organism), or the admixture of tissues from parental varieties resulting in a mixing of particular characteristics (such as sectorial, mericlinal and periclinal chimeras). Traditional taxonomy will be of little practical use as the artificial, reconstituted and merged biological organisms confound the traditional naming and characterising principles according to relationships and lineage. This has, however, been addressed in part by the naming codes showing that there is a viable solution. The International Code of Nomenclature for Cultivated Plants provides a practical illustration.

The International Code of Nomenclature for Cultivated Plants was introduced to address the plethora of characters found in plants under cultivation that differ significantly from their wild ancestors, or that warranted distinction from wild populations for horticultural purposes, ${ }^{179}$ and 'to promote uniformity, accuracy and fixity in the naming of agricultural, horticultural and silvicultural cultivars (varieties)' ${ }^{180}$ A further reason was the taxonomic complication posed specifically by plants as a consequence of outcrossing, self-crossing, apomixes, clonal propagation, polyploidy, and so on, that establish distinctive commercially useful variation not otherwise captured by the traditional taxonomic classifications and names. ${ }^{181}$ In essence, the International Code of Nomenclature for Cultivated Plants groups plants according to shared characters or features without a definitive reference to the parents or their lineage. ${ }^{182}$ Such organisms are often called 'cultigens' (or 'cultons') - organisms intentionally created, altered or selected by humans generally for a commercial purpose ${ }^{183}$ - and form the

178 For example, human nuclear DNA added to a denucleated cow embryo (including the cow's mitochondrial DNA): Woo-Suk Hwang's Application [2004] APO 24 (9 September 2004).

179 See, for example, Spencer et al (2007), pp 1-3. Domestication through human cultivation has a dramatic effect on the morphological characters so that a plethora of particular characters favoured by the human cultivators can be selected for and contribute to the classification. To illustrate this proposition for cultivation of tomatoes, see Darwin et al (2002); Jenkins (1948).

180 International Code of Nomenclature for Cultivated Plants, Art 3. See also McNeill (2008); Stearn (1986).

181 See Spooner et al (2002), p 21.

182 Notably removing the taxonomists' language of 'cultivar-group', 'selection', 'maintenance' and 'co-existence': see Brickell et al (2004), p xi.

183 See, for example, Bailey (1918). See also Spencer and Cross (2008); Hetterscheid and Brandenburg (1995a, 1995b). Notably, this language of 'taxon' and 'culton' was removed from the 1995 edition for the 2004 edition of the International Code of Nomenclature for Cultivated Plants to avoid arguments about relationship and application: see Brickell et al (2004), p xi. 
basis of naming rules under the code. ${ }^{184}$ The designation of 'cultigens' (or 'cultons') does not, however, entirely resolve the problems of taxonomy and naming codes because of the overlap between organisms treated as 'from nature' and 'cultivated', ${ }^{185}$ the ongoing confusion about overlapping names, little consensus about origins and defining characters, the complexity of the naming codes, and so on. ${ }^{186}$ The result was that the International Code of Nomenclature for Cultivated Plants has developed a more nuanced naming scheme for the 'purpose of giving a name to a distinguishable group of plants not to indicate its character or history, but to supply a means of referring to it'. ${ }^{187}$ Further, the code uses the terminology of 'cultivars' (cultivated variety), 'groups' and 'graft-chimeras', ${ }^{188}$ and expressly moved away from terms such as 'culton' and 'taxon' to avoid arguments about relationships and applications. ${ }^{189}$ In essence, the International Code of Nomenclature for Cultivated Plants modifies the taxonomic naming that might be applied under the International Code of Botanical Nomenclature to provide a means of usefully identifying and referring to cultivated plants: ${ }^{190}$ the name of the genus or lower taxonomic unit with a 'cultivar' or 'group' epithet (such as, for example, Fragaria ananassa 'Cambridge Favourite'). ${ }^{191}$ More importantly, however, the International Code of Nomenclature for Cultivated Plants has also established new naming rules, independent of the International Code of Botanical Nomenclature, for some 'graft-chimeras' (such as, for example, + Crataegus, Crataegus + Mespilus, and so on).$^{192}$ The term 'graft-chimeras' is defined as:

a plant that results from the grafting of the vegetative tissues of two or more plants belonging to different taxonomic units and is not a sexual hybrid ... Graft-chimeras below the rank of genus may be recognised as cultivars. ${ }^{193}$

These independent rules were necessary because the traditional taxonomy does not contemplate such organisms as their relationships are outside those addressed by taxonomy based on evolution, and the shared characters resulting from evolutionary adaptive mechanisms. ${ }^{194}$ In effect, the

\footnotetext{
184 International Code of Nomenclature for Cultivated Plants, Principle 2.

185 See, for example, Hetterscheid and Brandenburg (1995a, 1995b).

186 See, for example, Ochsmann (2003), p 44. See also Harlan and de Wet (1971).

187 International Code of Nomenclature for Cultivated Plants, Preamble 1.

188 International Code of Nomenclature for Cultivated Plants, Arts 2.1 ('cultivar'), 3.1 ('group') and 4.1 ('graft-chimeras').

189 See Brickell et al (2004), p xi.

190 International Code of Nomenclature for Cultivated Plants, Preamble 1 and Principles 1 and 4.

191 International Code of Nomenclature for Cultivated Plants, Arts 7.1, 19.1 and 20.1.

192 International Code of Nomenclature for Cultivated Plants, Arts 21.1-21.6.

193 International Code of Nomenclature for Cultivated Plants, Art 4.1.

194 See Spooner et al (2002), p 21.
} 
cultivated plant naming code for 'graft-chimeras' has supplemented the limitations of taxonomy by evolving a means of distinguishing organisms to reflect human interventions and meaningfully identify useful differences. Conceivably, other suitable naming codes might be developed and applied to any artificial, reconstituted and merged biological organisms. This solution may not be a comprehensive means to presently naming all the likely and possible artificial, reconstituted and merged biological organisms, even though these codes are evolving over time to address developing practices and trends. ${ }^{195}$ The potential to evolve demonstrates the arbitrariness of naming codes and that they do not provide a definitive standard albeit they may be a useful proxy for reducing organisms to the objects of law.

In conclusion, the analysis here demonstrates that taxonomy and the related means of naming may be a useful way of reducing organisms to objects of law, and that this is implicated from the imprints of taxonomy and naming in the PBR Act and the Patents Act. The analysis also demonstrates that the technological development of artificial, reconstituted and merged organisms may challenge the taxonomic basis of conceiving biological organisms, and that this can be - and to some extent is being - addressed through naming codes. Significantly, though, a reliance on the naming codes for this purpose necessitates a shift away from conceiving distinctions between organisms based on a hierarchy of relationships (taxonomy). In short, this will be a challenge to our understanding of 'algae', 'animals', 'fungi' and 'plants', as they are presently conceived in the language and application of taxonomy. This will also pose a challenge to the subjectmatter of the PBR Act through the ability of naming codes to capture technological developments that defy our exiting taxonomic conceptions of 'plants' including 'algae' and 'fungi', and the ongoing relevance of express exclusion of 'animals' and 'plants' from 'innovation patents' under the Patents Act.

The main contribution of the analysis and conclusions presented here is, however, to illustrate that neither law nor science can provide a definitive resolution to reducing biological organisms to the objects of law. The $P B R$ Act and the Patents Act appeal to taxonomy (and naming codes) as a means of definitively defining organisms as objects, and in turn, both taxonomy and naming codes fail to deliver as they too are unable to confer definitive definitions. While both law (through the PBR Act and the Patents Act) and science (through taxonomy and naming codes) appeals to certainty, this is an impossible paradox and neither can deliver. In a choice between two imperfect approaches, the result is that the law adopts a workable solution and declares the values that it essentially enshrines, albeit obfuscated in the authority of conventions practiced in other disciplines that themselves become the scaffolding of the law itself. While disappointing and anticlimactical when laid bare, it is pragmatic, and as the analysis of objectifying artificial, reconstituted and merged organisms demonstrates, it is elegantly pragmatic. 


\section{References}

\section{Secondary Sources}

Sina Adl, Alastair Simpson, Mark Farmer, Robert Andersen and Roger Anderson et al (2005)

'The New Higher Level Classification of Eukaryotes with Emphasis on the Taxonomy of Protists' 52 Journal of Eukaryotic Microbiology 399.

Thorsten Allers and Moshe Mevarech (2005) 'Archaeal Genetics - The Third Way' 6 Nature Reviews Genetics 58.

Tom Artois (2001) 'Phylogenetic Nomenclature: The End of Binomial Nomenclature?'

131 Belgian Journal of Zoology 87.

L Bailey (1918) 'The Indigen and Cultigen' 47 Science 306.

William Balch, Linda Magrum, George Fox, Ralph Wolfe and Carl Woese (1977) 'An Ancient

Divergence Among the Bacteria' 9 Journal of Molecular Evolution 305.

Arturo Becerra, Luis Delaye, Sara Islas and Antonio Lazcano (2007) 'The Very Early Stages of

Biological Evolution and the Nature of the Last Common Ancestor of the Three Major Cell Domains' 38 Annual Review of Ecology, Evolution, and Systematics 361.

Cédric Berney, José Fahrni and Jan Pawlowski (2004) 'How Many Novel Eukaryotic "Kingdoms"? Pitfalls and Limitations of Environmental DNA Surveys' 2 BMC Biology 13.

Yann Bertrand and Mikael Härlin (2006) 'Stability and Universality in the Application of Taxon Names in Phylogenetic Nomenclature' 55 Systematic Biology 848.

Debashish Bhattacharya, Hwan Su Yoon and Jeremiah Hackett (2004) 'Photosynthetic Eukaryotes Unite: Endosymbiosis Connects the Dots' 26 BioEssays 50.

C Brickell, B Baum, W Hetterscheid, A Leslie and J McNeill et al (2004) International Code of Nomenclature for Cultivated Plants, $7^{\text {th }}$ ed, International Society for Horticultural Science.

Mark Blaxter (2004) 'The Promise of a DNA Taxonomy' 359 Philosophical Transactions of the Royal Society of London B: Biological Science 669.

James Brown (2003) 'Ancient Horizontal Gene Transfer' 4 Nature Reviews Genetics 121.

Harold Bryant and Philip Cantino (2002) 'A Review of Criticisms of Phylogenetic Nomenclature: Is Taxonomic Freedom the Fundamental Issue?’ 77 Biological Review 39.

Fabien Burki, Kamran Shalchian-Tabrizi, Marianne Minge, Åsmund Skjæveland and Sergey Nikolaev et al (2007) 'Phylogenomics Reshuffles the Eukaryotic Supergroups' 2(8) PLoS One 1 (e790).

Thomas Cavalier-Smith (1981) 'Eukaryote Kingdoms: Seven or Nine?' 14 Biosystems 461.

Thomas Cavalier-Smith (1998) 'A Revised Six-Kingdom System of Life' 73 Biological Reviews 203.

Thomas Cavalier-Smith (2004) 'Only Six Kingdoms of Life' 271 Philosophical Transactions of the Royal Society of London B: Biological Science 1251.

J Corliss (1984) 'The Kingdom Protista and its 45 Phyla' 17 BioSystems 87.

Sarah Darwin, Sandra Knapp and Iris Peralta (2002) 'Taxonomy of Tomatoes in the Galapagos Islands: Native and Introduced Species of Solanum Section Lycopersicon (Solanaceae)' 1 Systematics and Biodiversity 29.

Benoît Dayrat (2005) 'Advantages of Naming Species Under the PhyloCode: An Example of How a New Species of Discodorididae (Mollusca, Gastropoda, Euthyneura, Nudibranchia, Doridina) May be Named' 1 Marine Biology Research 216.

Kevin de Queiroz and Jacques Gauthier (1992) 'Phylogenetic Taxonomy' 23 Annual Review of Ecology and Systematics 449.

Kevin de Queiroz and Phil Cantino (2001) 'Taxon Names, Not Taxa, are Defined' 50 Taxon 821.

Kevin de Queiroz (2007) 'Toward an Integrated System of Clade Names' 56 Systematic Biology 956. 
Martin Embley and William Martin (2006) 'Eukaryotic Evolution, Changes and Challenges' 440 Nature 623.

Kirk Fitzhugh (2008) "Abductive Inference: Implications for "Linnean" and "Phylogenetic" Approaches for Representing Biological Systematization' 35 Evolutionary Biology 52.

David Gledhill (2008) The Names of Plants, $4^{\text {th }}$ ed, Cambridge University Press.

H Godfray, Benjamin Clark, Ian Kitching, S Mayo and Malcolm Scoble (2007) 'The Web and the Structure of Taxonomy' 56 Systematic Biology 943.

Stephen Jay Gould (2002) The Structure of Evolutionary Theory, Belknap Press.

Werner Greuter (2000) 'Botanical Nomenclature Today and Tomorrow', in Bertil Nordenstam, Gamal El-Ghazaly and Mohamed Kassas (eds), Plant Systematics for the $21^{\text {st }}$ Century, Wenner-Gren International.

G Griffiths (1976) 'The Future of Linnaean Nomenclature' 25 Systematic Zoology 168.

Jeremiah Hackett, Hwan Su Yoon, Shenglan Li, Adrian Reyes-Prieto, Susanne Rümmele and Debashish Bhattacharya (2007) 'Phylogenomic Analysis Supports the Monophyly of Cryptophytes and Haptophytes and the Association of Rhizaria with Chromalveolates' 24 Molecular Biology and Evolution 1702.

J Harlan and J de Wet (1971) 'Toward a Rational Classification of Cultivated Plants' 20 Taxon 50.

Mikael Härlin (2003) 'Taxon Names as Paradigms: The Structure of Nomenclatural Revolutions' 19 Cladistics 138.

W Hetterscheid and W Brandenburg (1995a) 'Culton Versus Taxon: Conceptual Issues in Cultivated Plant Systematics’ 44 Taxon 161.

W Hetterscheid and W Brandenburg (1995b) 'The Culton Concept: Setting the Stage for an Unambiguous Taxonomy of Cultivated Plants' 413 Acta Horticulturae 29.

Stephen Hubicki and Brad Sherman (2009) 'We Have Never Been Modern: The High Court of Australia's Decision in National Research Development Corporation v Commissioner of Patents', in Andrew Kenyon, Megan Richardson and Sam Ricketson (eds), Landmarks in Australian Intellectual Property Law, Cambridge University Press.

J Jenkins (1948) ‘The Origin of the Cultivated Tomato' 2 Economic Botany 379.

Jocelyn Kaiser (2007) 'Attempt to Patent Artificial Organism Draws Protest' 316 Science 1557.

Patrick Keeling, Gertraud Burger, Dion Durnford, Franz Lang and Robert Lee et al (2005) 'The Tree of Eukaryotes' 20 Trends Ecology and Evolution 670.

Eugene Koonin (2007) 'The Biological Big Bang Model for the Major Transitions in Evolution' 2 Biology Direct 21.

Eugene Koonin (2009) 'Darwinian Evolution in the Light of Genomics' 37 Nucleic Acids Research 1011.

Matjaz Kuntner and Ingi Agnarsson (2006) 'Are the Linnean and Phylogenetic Nomenclatural Systems Combinable? Recommendations for Biological Nomenclature' 55 Systematic Biology 774.

Carole Lartigue, Sanjay Vashee, Mikkel Algire, Ray-Yuan Chuang and Gwynedd Benders et al (2009) 'Creating Bacterial Strains from Genomes that have been Cloned and Engineered in Yeast' 325 Science 1693.

Michel Laurin and Philip Cantino (2007) 'Second Meeting of the International Society for Phylogenetic Nomenclature: A Report' 36 Zoologica Scripta 109.

Michel Laurin (2008) 'The Splendid Isolation of Biological Nomenclature' 37 Zoologica Scripta 223.

Jeffrey Lawrence, Graham Hatfull and Roger Hendrix (2002) 'Imbroglios of Viral Taxonomy: Genetic Exchange and Failings of Phenetic Approaches' 184 Journal of Bacteriology 4891.

Charles Lawson (2004) 'Patenting Genetic Materials: Unresolved Issues and Promoting Competition in Biotechnology' 16 Information Economics and Policy 91. 
Charles Lawson (2006) 'Revisiting the Commonwealth Parliament's Legislative Authority for Patent and Patent-like Schemes Under the Constitution' 17 Australian Intellectual Property Journal 243.

Charles Lawson (2008) 'Grant $v$ Commissioner of Patents and Patenting Knowledge Inventions' 15 Journal of Law and Medicine 626.

Charles Lawson (2009) "Human Beings" as Excluded Subject-matter for the Purposes of the Patents Act 1990 (Cth)' 20 Australian Intellectual Property Journal 223.

Karinne Ludlow (1999a) 'Genetically Modified Organisms and Trade Mark Protection' 10 Australian Intellectual Property Journal 23.

Karinne Ludlow (1999b) 'My Pig is a Work of Art: Copyright Protection for Genetically Modified Organisms in Australia' 4 Media and Arts Law Review 41.

Michael Lynch (2007) 'The Frailty of Adaptive Hypotheses for the Origins of Organismal Complexity' 104 Proceedings of the National Academy of Sciences of the United States of America 8597.

Macquarie Library (2006) Macquarie: Australia's National Dictionary, Macquarie Library.

W Mat, H Xue and J Wong (2008) 'The Genomics of LUCA' 13 Frontiers in Bioscience 5605.

Ernst Mayr (1990) 'A Natural System of Organisms' 348 Nature 491.

Gordon McOuat (2006) 'Species, Rules and Meaning: The Politics of Language and the Ends of Definitions in 19th Century Natural History' 27 Studies in History and Philosophy of Science 473.

J McNeill (2008) 'The Taxonomy of Cultivated Plants' 799 Acta Horticulturae 21.

J McNeill, T Stuessy, N Turland and E Hörandl (2005) 'XVII International Botanical Congress: Preliminary Mail Vote and Report of Congress Action on Nomenclature Proposals' 54 Taxon 1057.

Ryan Mehl, Christopher Anderson, Stephen Santoro, Lei Wang and Andrew Martin et al (2003) 'Generation of a Bacterium with a 21 Amino Acid Genetic Code' 125 Journal of the American Chemical Society 935.

Ann Monotti (2006) 'The Scope of "Manner of Manufacture" Under the Patents Act 1990 (Cth) after Grant v Commissioner of Patents' 34 Federal Law Review 461.

Staffan Müller-Wille (2003) 'Nature as Marketplace: The Political Economy of Linnaean Botany' 35 History of Political Economy 154.

A Mushegian (2008) 'Gene Content of LUCA, the Last Universal Common Ancestor' 13 Frontiers in Bioscience 4657.

Karen Nelson, Rebecca Clayton, Steven Gill, Michelle Gwinn and Robert Dodson et al (1999) 'Evidence for Lateral Gene Transfer between Archaea and Bacteria from Genome Sequence of Thermotoga maritime' 399 Nature 323.

Dan Nicolson (1991) 'A History of Botanical Nomenclature' 78 Annals of the Missouri Botanical Garden 33.

J Ochsmann (2003) 'Some Notes on Problems of Taxonomy and Nomenclature of Cultivated Plants', in H Knüpffer and J Ochsmann (eds), Rudolf Mansfeld and Plant Genetic Resources, 22 Schriften zu Genetischen Ressourcen 42.

Hervé Philippe, Elizabeth Snell, Eric Bapteste, Philippe Lopez, Peter Holland and Didier Casane (2004) 'Phylogenomics of Eukaryotes: Impact of Missing Data on Large Alignments' 21 Molecular Biology and Evolution 1740.

Justine Pila (2003) 'Inherent Patentability in Anglo-Australian Law: A History' 14 Australian Intellectual Property Journal 109.

Michael Rappé and Stephen Giovannoni (2003) 'The Uncultured Microbial Majority' 57 Annual Review of Microbiology 369.

Andrew Roger and Laura Hug (2006) 'The Origin and Diversification of Eukaryotes: Problems with Molecular Phylogenetics and Molecular Clock Estimation' 361 Philosophical Transactions of the Royal Society B 1039. 
Andrew Roger and Alastair Simpson (2009) 'Evolution: Revisiting the Root of the Eukaryote Tree' 19 Current Biology R165.

Jeffrey Schwartz and Bruno Maresca (2006) 'Do Molecular Clocks Run at All? A Critique of Molecular Systematics' 1 Biological Theory 357.

Brad Sherman (2008) 'Taxonomic Property' 67 Cambridge Law Journal 560.

Alastair Simpson and Andrew Roger (2004) 'The Real 'Kingdoms' of Eukaryotes' 14 Current Biology R693.

Roger Spencer, Robert Cross and Peter Lumley (2007) Plant Names: A Guide to Botanical Nomenclature, $3^{\text {rd }}$ ed, CSIRO.

Roger Spencer and Rob Cross (2008) 'The Cultigen’ 799 Acta Horticulturae 163.

David Spooner, Wilbert Hetterscheid, Ronald van den Berg and Willem Brandenberg (2002) 'Plant Nomenclature and Taxonomy: An Horticultural and Agronomic Perspective' 28 Horticultural Reviews 21.

P Stearn (1986) 'Historical Survey of the Naming of Cultivated Plants' 182 Acta Horticulturae 19.

Emma Steenkamp, Jane Wright and Sandra Baldauf (2005) 'The Protistan Origins of Animals and Fungi' 23 Molecular Biology and Evolution 93.

Peter Stevens (2006) 'An End to All Things? - Plants and Their Names' 19 Australian Systematic Botany 115.

Hwan Su Yoon, Jessica Grant, Yonas Tekle, Min Wu and Benjamin Chaon et al (2008) 'Broadly Sampled Multigene Trees of Eukaryotes' 8 BMC Evolutionary Biology 14.

Kevin Thiele and David Yeates (2002) 'Tension Arises from Duality at the Heart of Taxonomy' 419 Nature 337.

Terrence Tumpey, Christopher Basler, Patricia Aguilar, Hui Zeng and Alicia Solórzano et al (2005) 'Characterization of the Reconstructed 1918 Spanish Influenza Pandemic Virus' 310 Science 77.

David Walsh and Ford Doolittle (2005) 'The Real "Domains" of Life' 15 Current Biology R237.

Laura Wegener Parfrey, Erika Barbero, Elyse Lasser, Micah Dunthorn and Debashish Bhattacharya et al (2006) 'Evaluating Support for the Current Classification of Eukaryotic Diversity' 2(12) PLoS Genetics 2062 (e220).

Quentin Wheeler (2004) 'Taxonomic Triage and the Poverty of Phylogeny' 359 Philosophical Transactions of the Royal Society of London B: Biological Science 571.

Robert Whittaker (1969) 'New Concepts of Kingdoms of Organisms' 163 Science 150.

E Wiley (1979) 'An Annotated Linnaean Hierarchy, with Comments on Natural Taxa and Competing Systems' 28 Systematic Zoology 308.

Carl Woese and George Fox (1977) 'Phylogenetic Structure of the Prokaryotic Domain: The Primary Kingdom' 74 Proceedings of the National Academy of Sciences of the United States of America 5088.

Carl Woese (2000) 'Interpreting the Universal Phylogenetic Tree' 97 Proceedings of the National Academy of Sciences USA 8392.

Carl Woese, Otto Kandler and Mark Wheelis (1990) 'Towards a Natural System of Organisms: Proposal for the Domains Archaea, Bacteria, and Eucarya' 87 Proceedings of the National Academy of Sciences USA 4576.

Yuri Wolf, Igor Rogozin, Nick Grishin and Eugene Koonin (2002) 'Genome Trees and the Tree of Life' 18 Trends in Genetics 472. 


\section{Institutional Reports and Documents}

Advisory Council on Intellectual Property (2004), Should Plant and Animal Subject-matter Be Excluded from Protection by the Innovation Patent?, IP Australia.

Advisory Council on Intellectual Property (2008) Patentable Subject-matter, Issues Paper, IP Australia.

American Type Culture Collection (2008) Budapest Treaty Deposit Form (BP/1), American Type Culture Collection.

Australian Law Reform Commission (2004a), Genes and Ingenuity, Report 99, SOS Printing Group.

Australian Law Reform Commission (2004b), Gene Patenting and Human Health, Discussion Paper, SOS Printing Group.

Commonwealth, Hansard, House of Representatives, 29 June 2000, p 18584 (Warren Entsch, Parliamentary Secretary to the Minister for Industry, Science and Resources).

Expert Panel on Breeding (2002) Clarification of Plant Breeding Issues Under the Plant Breeder's Rights Act 1994, Plant Breeder's Rights Office.

Explanatory Memorandum (1989) Patents Bill 1989 (Cth), Australian Government Printing Service.

Explanatory Memorandum (Revised) (2000), Patents Amendment (Innovation Patents) Bill 2000 (Cth), Senate Printing.

Industrial Property Advisory Council (1984) Patents, Innovation and Competition in Australia, Australian Government Printing Service.

International Union for the Protection of New Varieties of Plants (2006) Explanatory Notes on Variety Denominations under the UPOV Convention, UPOV/INF/12/1, International Union for the Protection of New Varieties of Plants.

IP Australia (2005) Australian Patents for Biological Inventions, IP Australia.

IP Australia (2010a) Australian Patent Office: Manual of Practice and Procedures, IP Australia.

IP Australia (2010b) The Budapest Treaty and Australian Patents, IP Australia.

Lady Mary Fairfax CellBank Australia (2009) Statement in the Case of an Original Deposit, CellBank Australia.

National Measurement Institute (2008) Statement in the Case of an Original Deposit, National Measurement Institute.

Patent Office Notice (1980) 50 AOJP 1162.

Registrar of Plant Breeder's Rights (2009) List of Plant Classes, IP Australia.

Standing Committee on Legal and Constitutional Affairs, House of Representatives (2001) Human Cloning: Scientific, Ethical and Regulatory Aspects of Human Cloning and Stem Cell Research, Senate Printing.

World Intellectual Property Organisation (2010) Guide to the Deposit of Microorganisms under the Budapest Treaty, World Intellectual Property Organisation.

\section{Codes}

International Code of Botanical Nomenclature - J McNeill, F Barrie, H Burdet, V Demoulin, D Hawksworth, K Marhold, D Nicolson, J Prado, P Silva, J Skog, J Wiersema and N Turland (2006) International Code of Botanical Nomenclature, Gantner Verlag KG.

International Code of Nomenclature for Cultivated Plants - C Brickell, B Baum, W Hetterscheid, A Leslie, J McNeill, P Trehane, F Vrugtman and J Wiersema (2004) 
International Code of Nomenclature for Cultivated Plants, $7^{\text {th }}$ ed, International Society for Horticultural Science.

International Code of Nomenclature of Bacteria - S Lapage, P Sneath, E Lessel, V Skerman, H Seeliger and W Clark (1992) International Code of Nomenclature of Bacteria (1990 rev), ASM Press.

International Code of Virus Classification and Nomenclature - International Committee for the Taxonomy of Viruses (1999) International Code of Virus Classification and Nomenclature, International Committee for the Taxonomy of Viruses.

International Code of Zoological Nomenclature - W Ride, H Cogger, C Dupuis, O Kraus, A Minelli, F Thompson and P Tubbs (1999) International Code of Zoological Nomenclature, $4^{\text {th }} \mathrm{ed}$, International Trust for Zoological Nomenclature.

\section{Conventions}

Budapest Treaty - Budapest Treaty on the International Recognition of the Deposit of Microorganisms for the Purposes of Patent Procedure [1987] ATS 9.

Budapest Treaty Regulations - Regulations Under the Budapest Treaty on the International Recognition of the Deposit of Microorganisms for the Purposes of Patent Procedure, International Bureau of WIPO.

European Patents Convention - Convention on the Grant of European Patents (1973) 13 ILM 268.

UPOV - International Convention for the Protection of New Varieties of Plants [2000] ATS 6.

\section{Cases}

Advanced Building Systems Pty Limited v Ramset Fasteners (Aust) Pty Limited (1998) 194 CLR 171

AMP Inc v Utilux Pty Ltd (1971) 45 ALJR 123

Diamond v Chakrabarty 447 US 303 (1980)

Grain Pool of Western Australia v Commonwealth (2000) 202 CLR 479

Kimberly-Clark Australia Pty Ltd v Arico Trading International Pty Ltd (2001) 207 CLR 1

National Research Development Corporation v Commissioner of Patents (1959) 102 CLR 252

No-Fume Ltd v Frank Pitchford \& Co (1935) 52 RPC 231

Novartis/Transgenic Plant G01/98 [2000] EPOR 303

NV Philips Gloeilampenfabrieken and Philips Lighting Pty Ltd v Mirabella International Pty Ltd (1995) 183 CLR 655

Plant Bioscience/Broccoli T0083/05 (2007) 12 Official Journal of the European Patent Office 644

Ranks Hovis McDougall Ltd's Application (1976) 46 AOJP 3915

Rescare Ltd v Anaesthetic Supplies Pty Ltd (1992) 111 ALR 205

Woo-Suk Hwang's Application [2004] APO 24 (9 September 2004)

\section{Legislation}

Federal Court of Australia Act 1976 (Cth)

Patents Act 1990 (Cth)

Patents Amendment (Innovation Patents) Act 2000 (Cth)

Patents Regulations 1991 (Cth)

Plant Breeder's Rights Act 1994 (Cth) 